\title{
Optimal Capital Structure Vs. Pecking Order Theory: A Further Test
}

Arvin Ghosh, (E-mail: ghosha@wpunj.edu), William Paterson University Francis Cai, (E-mail: caif@wpunj.edu), William Paterson University

\begin{abstract}
In this paper we have used the Compustat data-set covering 1983-2003 to test empirically whether a firms' capital structure follows "optimal capital structure" or" pecking order theory"(POT) as advanced by Professor Stewart Myers. Using the industry mean as a predictor of a firm's capital structure, we have found that in general, a firm's debt level is moving toward the industry's mean is not significantly different from that it is moving further away from the industry mean, while a firm's debt level is moving toward the industry mean is very high when it is above the industry mean.
\end{abstract}

The empirical result suggests that the optimal capital structure is not a single point, rather a range of values from zero to the industry mean within which a typical U.S. firm will be indifferent to the firm's debt level. In other words, a firm will only adjust to the optimal capital structure when the firm's debt level is out of this range. Out result also generally agrees with the pecking order theory, that is, firms prefer using internal financing as opposed to using external financing. Furthermore, when external funds are required, a firm prefers debt financing to equity financing.

\section{Introduction}

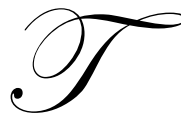

he optimal capital structure theory evolved through the writings of Franco Modigliani and Merton Miller (MM, 1958). At first they proposed that, in a world of no income taxes and transaction costs, a firm's capital structure is irrelevant to its value. But with the introduction of corporation income taxes and transaction costs (MM, 1963), it was proposed that a firm would use its debt financing judiciously so that its tax saving would balance its chance of potential bankruptcy. Hence the evolution of the notion of optimal capital structure where the debt/equity mix would be such that the firm's weighted average cost of capital would be minimized and its value would be maximized. DeAngelo and Masulis in their famous 1980 article had articulated in such a way that the proposition came to be known as the "optimal capital structure."

In 1982 Bowen, Daley and Huber, Jr. (BDH) had provided a technique by which we can test the optimal capital structure. They proposed that an individual firm's debt structure tend to converge to its industry mean over time. Marsh (1982) had concluded that "companies do appear to make the choice of financing instrument as though they had target levels in mind for both long-term debt ratios and the ratio of short-term to total debt." Stewart Myers in his seminal article (1984) had proposed the pecking order theory (POT) -- that firms choose internal capital at first, i.e., the use of retained earnings. And when external capital is needed, they choose debt capital, and only equity capital as the last resort. Taggart (1986) used POT in his study of capital structure and found that the pecking order hypothesis was more valid than the optimal capital structure hypothesis.

More recently, E.T. Claggett, Jr. (1992) tested the optimal capital structure theory and had found that long-term debt to total assets ratio, for the most part, tended to move toward the most recent previous industry mean within one year. I general, in more firms with above the industry mean long-term debt ratios adjusted toward the industry mean 
than with below the industry mean ratios. Claggett, Jr. also found that firms normally behave in a manner consistent with the pecking order theory, but some firms may not adjust during periods of severe turmoil.

In our previous article (1999), we also had tested both the optimal capital structure hypothesis and pecking order hypothesis and found that firms would adjust their capital structure toward the industry mean when it was above the mean, but that firms below the industry mean would adjust their capital structure toward the industry mean rather sluggishly. But our study had also shown that both the optimal capital structure hypothesis and the pecking order hypothesis coexisted during the period covered by our study (1974-1992). In that article we had used the data collected from Fortune magazine's largest 500 United States companies. Here we will test the two hypothesis anew with the help of Compustat data-base. Also, we will advance the years from 1983 to 2001 in order to take up more recent time period of the United States industries.

\section{Methodological Framework}

To test the optimal capital structure theory we have employed two methodologies in this paper. The first methodology we have pursued here was introduced by BDH first and later refined by E. T. Claggett, Jr. where a two-by-two contingency table was formulated. The nonparametric Fisher Exact Probability (FEP) test and later the Goodman-Kruskal Gamma measures were employed to analyze the data. To examine whether firms converge their capital structure toward their industry mean, the two-by-two matrix was analyzed for each year (across industry) and each industry (across year) in the following manner:

\section{Figure 1}

\begin{tabular}{cc}
\hline $\begin{array}{c}\text { Number of firms below }(\mathrm{L}) \\
\text { that did correct }\end{array}$ & $\begin{array}{c}\text { Number of firms below }(\mathrm{L}) \\
\text { that did not correct }\end{array}$ \\
\hline $\begin{array}{c}\text { Number of firms above }(\mathrm{H}) \\
\text { that did not correct }\end{array}$ & $\begin{array}{c}\text { Number of firms above }(\mathrm{H}) \\
\text { that did correct }\end{array}$ \\
\hline
\end{tabular}

The hypothesis tested by this procedure is that gamma is significantly different from zero. If there is no statistical significance we conclude that there is no discernable trend to move toward or away from the industry mean capital structure. The results are shown in Tables 1 through 4.

To test the POT, a two-by-four matrix was analyzed for each industry (across year), for each year (across industry), and for all observations pooled. Figure 2 describes the matrix:

\section{Figure 2}

\begin{tabular}{llll}
\hline $\begin{array}{l}\text { Number of firms } \\
\text { below (L) that } \\
\text { passive (P) }\end{array}$ & $\begin{array}{l}\text { Number of firms } \\
\text { below (L) that } \\
\text { issued debt (D) }\end{array}$ & $\begin{array}{l}\text { Number of firms } \\
\text { below (L) that } \\
\text { issued equity(E) }\end{array}$ & $\begin{array}{l}\text { Number of firms } \\
\text { below (L) that } \\
\text { issued both (B) }\end{array}$ \\
$\begin{array}{l}\text { Number of firms } \\
\text { above (H) that } \\
\text { were passive(P) }\end{array}$ & $\begin{array}{l}\text { Number of firms } \\
\text { above (H) that } \\
\text { issued debt (D) }\end{array}$ & $\begin{array}{l}\text { Number of firms } \\
\text { above (H) that } \\
\text { issued equity(E) }\end{array}$ & $\begin{array}{l}\text { Number of firms } \\
\text { above (H) that } \\
\text { issued both (B) }\end{array}$ \\
\hline
\end{tabular}

For each Figure 2 matrix, an estimate of $G$ and the associated test statistic $(Z)$ were calculated. Here the hypothesis is that $\mathrm{G}$ is significantly different from zero. If there is no significance, we conclude that there is no support for Pecking Order Theory. But if G is significant and the sign is positive (+), we will interpret that as a corroboration of the POT. The result is shown in Table 5 and 6. 


\section{Empirical Results}

In Table 1, we find that for the measure of LTD/TA, 18 out of the 21 industries had Z statistics which were positive and significant either at the 1 percent or 5 percent level (two-tail test). For the measure of TD/TA, 19 industries had significant $\mathrm{Z}$ statistics, while for the measure of TE/TA, 19 industries also had significant $\mathrm{Z}$ statistics either at the 1 percent or 5 percent level. The pooled data also shows this tendency toward convergence when the $\mathrm{Z}$ statistics for all of the three measures were significant at 1 percent level. These results strongly indicate that firms do converge toward their respective industry mean, thus supporting the optimal capital structure hypothesis.

\section{Table 1: Summary of Capital Structure Symmetric Convergence, By Industry 1983-2001}

LTD/TA-- Long term debt over total assets; TD/TA--- Total debt over total assets; TE/TA--- Total equity over total assets.

\begin{tabular}{|c|c|c|c|c|c|c|c|}
\hline \multirow[b]{2}{*}{ Industry } & \multicolumn{3}{|c|}{ LTD/TA } & \multirow{2}{*}{$\frac{\text { TD/TA }}{\text { Gamma }}$} & \multicolumn{3}{|c|}{ TE/TA } \\
\hline & Obs. & $\overline{\text { Gamma }}$ & Z-Tes & & Z-Test & Gamma & Z-Test \\
\hline Aerospace & 290 & 0.138 & 1.675 & 0.339 & $4.339 * *$ & 0.357 & $4.598 * *$ \\
\hline Apparel & 780 & 0.532 & $12.393 * *$ & 0.133 & $2.660 * *$ & 0.575 & $13.89 * *$ \\
\hline Beverage & 123 & 0.577 & $5.538 * *$ & 0.260 & $2.111^{*}$ & 0.261 & $2.124 *$ \\
\hline Building Materials & 117 & 0.317 & $2.560 *$ & 0.208 & 1.630 & 0.088 & 0.677 \\
\hline Chemicals & 258 & 0.416 & $5.201 * *$ & 0.371 & $4.534 * *$ & 0.288 & $3.421 * *$ \\
\hline Computers, Office Equip. & 243 & 0.518 & $6.669 * *$ & 0.368 & $4.360 * *$ & 0.494 & $6.270 * *$ \\
\hline Electronics, Elec. Equip. & 454 & 0.391 & $6.409 * *$ & 0.364 & $5.892 * *$ & 0.444 & $7.470 * *$ \\
\hline Food & 345 & 0.424 & $6.148 * *$ & 0.418 & $6.038 * *$ & 0.463 & $6.852 * *$ \\
\hline Forest Products & 389 & 0.497 & $7.980 * *$ & 0.425 & $6.545^{* *}$ & 0.569 & $9.654 * *$ \\
\hline Industrial \& Farm Equip. & 260 & 0.250 & $2.938 * *$ & 0.332 & $4.012 * *$ & 0.245 & $2.880 * *$ \\
\hline Metal Products & 224 & 0.395 & $4.551 * *$ & 0.248 & $2.711 * *$ & 0.292 & $3.235^{* *}$ \\
\hline Metals & 290 & 0.015 & 0.176 & 0.426 & $5.670 * *$ & 0.366 & $4.733 * *$ \\
\hline Mining, Crude oil Prod. & 130 & 0.302 & $2.555^{*}$ & 0.553 & $5.351 * *$ & 0.436 & $3.906 * *$ \\
\hline Motor Vehicles \& Parts & 356 & 0.246 & $3.384 * *$ & 0.424 & $6.240 * *$ & 0.201 & $2.736 * *$ \\
\hline Petroleum Refining & 987 & 0.266 & $6.127 * *$ & 0.360 & $8.567 * *$ & 0.346 & $8.189 * *$ \\
\hline Pharmaceuticals & 330 & 0.520 & $7.823 * *$ & 0.478 & $6.981 * *$ & 0.610 & $9.901 * *$ \\
\hline Publishing, Printing & 458 & 0.423 & $7.070 * *$ & 0.400 & $6.597 * *$ & 0.488 & $8.469 * *$ \\
\hline Sci. \& Photo Equip. & 232 & 0.394 & $4.615 * *$ & 0.406 & $4.787 * *$ & 0.377 & $4.385 * *$ \\
\hline Soaps, Cosmetics & 267 & 0.509 & $6.836^{* *}$ & 0.460 & $5.985 * *$ & 0.325 & $3.967 * *$ \\
\hline Textile & 126 & 0.167 & 1.340 & 0.040 & 0.317 & 0.171 & 1.378 \\
\hline Tobacco & 114 & 0.355 & $2.867 * *$ & 0.040 & 0.300 & 0.370 & $3.003 * *$ \\
\hline Total & 6773 & 0.309 & $18.903 * *$ & 0.391 & $24.743 * *$ & 0.398 & $25.22 * *$ \\
\hline
\end{tabular}

* significant at $5 \%$ level.

** significant at $1 \%$ level.

Table 2 shows he convergence toward the industry mean within one year. Here, for the LTD/TA measure of capital structure the Z statistics were significant in 17 out of 19 years, either at the 1 percent or 5 percent level. But for the TD/TA measure of capital structure, the $\mathrm{Z}$ statistics were significant only in 10 out of 19 years.

However, the results were much better for the industry convergence when TE/TA measure was taken into account. Here the $\mathrm{Z}$ statistics were significant in 14 out of 19 years. The pooled data were also significant at the 1 percent level for all the three measures of capital structure. Thus both Tables 1 and 2 support the conclusions reached by Jalilvand and Harris (1984), Lev (1969), Marsh (1982), and Claggett, Jr. (1992), but not by BDH (1982), where they found no significant convergence over one-year intervals. 
Table 2: Summary of Capital Structure Symmetric Convergence, By Year 1983-2001

LTD/TA-- Long term debt over total assets; TD/TA--- Total debt over total assets; TE/TA--- Total equity over total assets.

\begin{tabular}{|c|c|c|c|c|c|c|c|}
\hline \multirow[b]{2}{*}{ Year } & \multicolumn{3}{|c|}{ LTD/TA } & \multirow{2}{*}{$\begin{array}{l}\text { TD/TA } \\
\text { Gamma }\end{array}$} & \multicolumn{3}{|c|}{ TE/TA } \\
\hline & Obs. & Gamma & Z-Test & & Z-Test & Gamma & Z-Test \\
\hline 1983 & 297 & 0.368 & $4.822 * *$ & 0.358 & $4.667 * *$ & 0.312 & $4.005^{* *}$ \\
\hline 1984 & 314 & 0.326 & $4.321 * *$ & 0.301 & $3.953 * *$ & 0.281 & $3.669 * *$ \\
\hline 1985 & 318 & 0.199 & $2.567 *$ & 0.194 & $2.491 *$ & 0.336 & $4.501 * *$ \\
\hline 1986 & 320 & 0.225 & $2.915 * *$ & 0.140 & 1.785 & 0.149 & 1.911 \\
\hline 1987 & 321 & 0.214 & $2.779 * *$ & 0.082 & 1.048 & 0.202 & $2.614 * *$ \\
\hline 1988 & 332 & 0.396 & $5.550 * *$ & 0.094 & 1.222 & 0.096 & 1.243 \\
\hline 1989 & 334 & 0.140 & 1.833 & 0.099 & 1.280 & 0.168 & $2.203^{*}$ \\
\hline 1990 & 350 & 0.369 & $5.245^{* *}$ & 0.134 & 1.784 & 0.019 & 0.252 \\
\hline 1991 & 352 & 0.201 & $2.722 * *$ & 0.219 & $2.976^{* *}$ & 0.034 & 0.453 \\
\hline 1992 & 353 & 0.405 & $5.880 * *$ & 0.322 & $4.518 * *$ & 0.276 & $3.811 * *$ \\
\hline 1993 & 360 & 0.122 & 1.650 & 0.098 & 1.325 & 0.203 & $2.776^{* * *}$ \\
\hline 1994 & 371 & 0.194 & $2.690 * *$ & 0.110 & 1.507 & 0.185 & $2.568^{*}$ \\
\hline 1995 & 379 & 0.941 & $38.408 * *$ & 0.003 & 0.043 & 0.151 & $2.108^{*}$ \\
\hline 1996 & 384 & 0.357 & $5.287 * *$ & 0.283 & $4.087 * *$ & 0.410 & $6.230 * *$ \\
\hline 1997 & 384 & 0.255 & $3.657 * *$ & 0.948 & $41.442 * *$ & 0.986 & $80.95 * *$ \\
\hline 1998 & 395 & 0.183 & $2.621 * *$ & 0.147 & $2.082 *$ & 0.315 & $4.670 * *$ \\
\hline 1999 & 398 & 0.139 & $1.985^{*}$ & 0.121 & 1.726 & 0.286 & $4.208 * *$ \\
\hline 2000 & 400 & 0.201 & $2.908 * *$ & 0.153 & $2.192 *$ & 0.124 & 1.774 \\
\hline 2001 & 411 & 0.299 & $4.484 * *$ & 0.219 & $3.224 * *$ & 0.373 & $5.758 * *$ \\
\hline Total & 6773 & 0.309 & $18.903 * *$ & 0.391 & $24.743 * *$ & 0.398 & $25.22 * *$ \\
\hline
\end{tabular}

* Significant at $5 \%$ level.

** Significant at $1 \%$ level.

In Table 3, we have shown the summary of asymmetric convergence by industry during 1983-2001. This table strongly corroborates the conclusion of table 1 that the majority of firms had converged their LTD/TD ratios toward their industry means. Here 17 out of 21 industries had convergence with the $\mathrm{Z}$ statistics either at the 1 percent or at the 5 percent level of significance, while for the measure of TD/TA, 12 industries had convergence with the $\mathrm{Z}$ statistics significant either at the 1 percent or 5 percent level of significance. But in the case of TE/TA ratio, only 6 industries had convergence either at the 1 percent or 5 percent level of significance. Also, in the majority of industries the negative signs of the $\mathrm{Z}$ statistics meant that the convergence came from above. This again supports the results obtained by Claggett, Jr. (1992), that the convergence toward the industry mean came most often from firms above their industry mean LTD/TA ratios. The pooled data for all these measures of capital structure also confirms the result of convergence which were significant at the 1 percent level of significance.

In Table 4 we have calculated the gamma values and the $\mathrm{Z}$ statistics for the asymmetric convergence by year. We find that the $\mathrm{Z}$ statistics were significant in 14 out of 19 years for the LTD/TA measure, while for both the TD/TA and TE/TA measures, 11 out of 19 years had the $\mathrm{Z}$ statistics significant either at the 1 percent or 5 percent level of significance. Also, the negative signs for the majority of years (except for the TE/TA measure, meant that the convergence movement came from above, as seen in the case of the majority of industries. The pooled data for only the LTD/TA measure showed the negative sign, meaning that the convergence toward the industry mean came from the above. 
Table 3: Summary of Capital Structure Asymmetric Convergence, By Industry 1983-2001

LTD/TA-- Long term debt over total assets; TD/TA--- Total debt over total assets; TE/TA--- Total equity over total assets.

\begin{tabular}{|c|c|c|c|c|c|c|c|}
\hline \multirow[b]{2}{*}{ Industry } & \multicolumn{3}{|c|}{$\underline{\mathrm{LTD} / \mathrm{TA}}$} & \multirow{2}{*}{$\frac{\text { TD/TA }}{\text { Gamma }}$} & \multicolumn{3}{|c|}{ TE/TA } \\
\hline & Obs. & Gamma & Z-Test & & Z-Test & Gamma & Z-Test \\
\hline Aerospace & 90 & -0.531 & $-7.552 * *$ & -0.255 & $-3.181 * *$ & -0.140 & -1.698 \\
\hline Apparel & 80 & -0.487 & $-11.017 * *$ & -0.332 & $-6.945 * *$ & 0.051 & 1.003 \\
\hline Beverage & 23 & 0.443 & $3.870 * *$ & -0.062 & -0.487 & -0.505 & $-4.589 * *$ \\
\hline Building Materials & 17 & -0.414 & $-3.474 * *$ & 0.043 & 0.330 & -0.113 & -0.867 \\
\hline Chemicals & 58 & 0.180 & $2.083^{*}$ & -0.197 & $-2.283 *$ & -0.227 & $-2.642 * *$ \\
\hline Computers, Office Equip. & 243 & -0.144 & -1.602 & 0.029 & 0.319 & -0.080 & -0.882 \\
\hline Electronics, Elec. Equip & 454 & -0.417 & $-6.909 * *$ & -0.150 & $-2.293 *$ & 0.012 & 0.178 \\
\hline Food & 345 & -0.288 & $-3.949 * *$ & -0.167 & -2.227 & 0.008 & 0.100 \\
\hline Forest Products & 389 & -0.033 & -0.463 & -0.011 & -0.146 & -0.156 & $-2.206^{*}$ \\
\hline Industrial \& Farm Equip. & 260 & -0.224 & $-2.626 * *$ & -0.223 & $-2.609 * *$ & 0.065 & 0.744 \\
\hline Metal Products & 224 & -0.402 & $-4.639 * *$ & -0.127 & -1.358 & -0.026 & -0.279 \\
\hline Metals & 290 & -0.448 & $-6.040 * *$ & -0.352 & $-4.529 * *$ & -0.157 & -1.911 \\
\hline Mining, Crude oil Prod. & 130 & -0.175 & -1.430 & -0.107 & -0.871 & 0.133 & 1.079 \\
\hline Motor Vehicles \& Parts & 356 & -0.205 & $-2.797 * *$ & -0.231 & $-3.168 * *$ & 0.116 & 1.560 \\
\hline Petroleum Refining & 987 & -0.288 & $-6.670 * *$ & -0.245 & $-5.605 * *$ & -0.156 & $-3.513 * *$ \\
\hline Pharmaceuticals & 330 & -0.559 & $-8.668 * *$ & 0.022 & 0.288 & -0.130 & -1.679 \\
\hline Publishing, Printing & 458 & -0.281 & $-4.422 * *$ & -0.184 & $-2.838 * *$ & 0.034 & 0.521 \\
\hline Sci. \& Photo Equip. & 232 & -0.536 & $-6.833 * *$ & -0.153 & -1.670 & 0.263 & $2.930 * *$ \\
\hline Soaps, Cosmetics & 267 & 0.227 & $2.698 * *$ & 0.225 & $2.666 * *$ & 0.216 & $2.557 * *$ \\
\hline Textile & 126 & -0.443 & $-3.920 * *$ & -0.400 & $-3.468 * *$ & 0.122 & 0.972 \\
\hline Tobacco & 114 & -0.638 & -6.262 & 0.533 & $4.760^{* *}$ & 0.152 & 1.164 \\
\hline Total & 6773 & -0.330 & -20.323 & 0.165 & $9.714 * *$ & 0.081 & $4.740 * *$ \\
\hline
\end{tabular}

* Significant at $5 \%$ level.

** Significant at $1 \%$ level.

Table 4: Summary of Capital Structure Asymmetric Convergence, By Year 1983-2001

LTD/TA-- Long term debt over total assets; TD/TA--- Total debt over total assets; TE/TA--- Total equity over total assets.

\begin{tabular}{|c|c|c|c|c|c|c|c|}
\hline & & LTD/TA & TD/TA & & TE/TA & & \\
\hline Industry & Obs. & Gamma & Z-Test & Gamma & $\overline{\text { Z-Test }}$ & Gamma & Z-Test \\
\hline 1983 & 297 & -0.200 & $-2.461 *$ & 0.595 & $8.923 * *$ & 0.693 & $11.575 * *$ \\
\hline 1984 & 314 & 0.171 & $3.431 * *$ & -0.762 & $-23.25 * *$ & 0.542 & $12.724 * *$ \\
\hline 1985 & 318 & -0.761 & $-9.202 * *$ & -0.327 & $-2.712 * *$ & 0.224 & 1.799 \\
\hline 1986 & 320 & -0.550 & $-5.034 * *$ & -0.277 & $-2.206 *$ & 0.045 & 0.344 \\
\hline 1987 & 321 & 0.470 & $6.046^{* *}$ & -0.257 & -3.020 & -0.451 & $-5.739 * *$ \\
\hline 1988 & 332 & -0.642 & $-9.219 * *$ & 0.026 & 0.291 & -0.359 & $4.241 * *$ \\
\hline 1989 & 334 & -0.296 & $-4.671 * *$ & -0.199 & $-3.052 * *$ & 0.110 & 1.663 \\
\hline 1990 & 350 & -0.509 & $-7.758 * *$ & -0.317 & $-4.387 * *$ & 0.132 & 1.750 \\
\hline 1991 & 352 & 0.104 & 1.455 & -0.648 & $-11.861 * *$ & 0.284 & $4.124 * *$ \\
\hline 1992 & 353 & -0.579 & $-8.098 * *$ & -0.604 & $-8.645 * *$ & -0.257 & $-3.032 * *$ \\
\hline 1993 & 360 & -0.531 & $-6.637 * *$ & -0.081 & -0.857 & -0.219 & $-2.374 *$ \\
\hline 1994 & 371 & -0.180 & $-2.198 *$ & -0.219 & $-2.707 * *$ & -0.291 & $-3.658 * *$ \\
\hline 1995 & 379 & -0.025 & -0.200 & 0.026 & 0.213 & -0.086 & -0.693 \\
\hline 1996 & 384 & -0.120 & -1.609 & 0.106 & 1.417 & -0.428 & $-6.312 * *$ \\
\hline 1997 & 384 & -0.332 & $-7.814 * *$ & -0.129 & $-2.893 * *$ & -0.094 & $-2.086 *$ \\
\hline 1998 & 395 & -0.158 & $-2.057 *$ & -0.145 & -1.884 & -0.096 & -1.239 \\
\hline 1999 & 398 & -0.212 & $-3.280 * *$ & 0.116 & 1.766 & -0.152 & -2.327 \\
\hline 2000 & 400 & -0.044 & -0.473 & -0.303 & $-3.419 * *$ & 0.211 & $2.322 *$ \\
\hline 2001 & 411 & 0.129 & 1.507 & -0.095 & -1.102 & -0.051 & -0.596 \\
\hline Total & 6773 & -0.330 & -20.323 & 0.165 & $9.714 * *$ & 0.081 & $4.740^{* *}$ \\
\hline
\end{tabular}

* Significant at $5 \%$ level.

**Significant at $1 \%$ level. 
Table 5 shows the results for pecking order preference by industry during 1983-2001 for the LTD/TA measure of capital structure. Claggett, Jr. (1992) found strong support for pecking order behavior except for two industries - newspaper publishing and the retail sector. Here we find that all the industries taken in our sample had positive and significant Z-test for their gamma values at the 1 percent level of significance. The pooled data also corroborates this result which were highly significant at the 1 percent level of significance.

Table 6 presents the results for the pecking order preference by year during 1983-2001 for the LTD/TA measure. Again consistent with Claggett, Jr. (1992), all the years taken in our sample had positive and significant gamma values at the 1 percent level of significance. Furthermore, the pooled data showed that the gamma values were significant for all the years covered by our study at the 1 percent level of significance.

Table 5: Summary of Test for Pecking Order Preference By Industry, 1983-2001

\begin{tabular}{llcc}
\hline Industry & Obs. & Gamma & Z-test \\
\hline Aerospace & 290 & 0.593 & $8.875255^{* *}$ \\
Apparel & 780 & 0.723 & $20.67572^{* *}$ \\
Beverage & 123 & 0.642 & $6.574953^{* *}$ \\
Building Materials & 117 & 0.604 & $5.795713^{* *}$ \\
Chemicals & 258 & 0.684 & $10.63591^{* *}$ \\
Computers, Office Equip. & 243 & 0.781 & $13.77979^{* *}$ \\
Electronics, Elec. Equip. & 454 & 0.755 & $17.32723^{* *}$ \\
Food & 345 & 0.530 & $8.217197^{* *}$ \\
Forest Products & 389 & 0.579 & $9.913620^{* *}$ \\
Industrial \& Farm Equip. & 260 & 0.772 & $13.86212^{* *}$ \\
Metal Products & 224 & 0.610 & $8.156889^{* *}$ \\
Metals & 290 & 0.621 & $9.537569^{* *}$ \\
Mining, Crude oil Prod. & 130 & 0.529 & $5.031159^{* *}$ \\
Motor Vehicles \& Parts & 356 & 0.738 & $14.57250^{* *}$ \\
Petroleum Refining & 987 & 0.636 & $18.32556^{* *}$ \\
Pharmaceuticals & 330 & 0.571 & $8.926712^{* *}$ \\
Publishing, Printing & 458 & 0.671 & $13.67932^{* *}$ \\
Sci. \& Photo Equip. & 232 & 0.634 & $8.827903 * *$ \\
Soaps, Cosmetics & 267 & 0.683 & $10.79606^{* *}$ \\
Textile & 126 & 0.554 & $5.286185^{* *}$ \\
Tobacco & 114 & 0.566 & $5.179273^{* *}$ \\
Total & 6773 & 0.648 & $49.56342^{* *}$ \\
\hline
\end{tabular}

* Significant at $5 \%$ level.

** Significant at $1 \%$ level. 
Table 6: Summary of Test for Pecking Order Preference By Year, 1983-2001

\begin{tabular}{llll}
\hline Year & Obs. & Gamma & Z-test \\
\hline 1983 & 297 & 0.728 & $12.95068^{* *}$ \\
1984 & 314 & 0.740 & $13.79375^{* *}$ \\
1985 & 318 & 0.700 & $12.34297^{* *}$ \\
1986 & 320 & 0.688 & $12.00360^{* *}$ \\
1987 & 321 & 0.762 & $14.92497 * *$ \\
1988 & 332 & 0.627 & $10.38265^{* *}$ \\
1989 & 334 & 0.654 & $11.16777^{* *}$ \\
1990 & 350 & 0.716 & $13.55721^{* *}$ \\
1991 & 352 & 0.570 & $9.213560^{* *}$ \\
1992 & 353 & 0.692 & $12.74742^{* *}$ \\
1993 & 360 & 0.614 & $10.42675^{* *}$ \\
1994 & 371 & 0.682 & $12.68721^{* *}$ \\
1995 & 379 & 0.744 & $15.33496 * *$ \\
1996 & 384 & 0.641 & $11.57363 * *$ \\
1997 & 384 & 0.703 & $13.69777^{* *}$ \\
1998 & 395 & 0.602 & $10.59079^{* *}$ \\
1999 & 398 & 0.703 & $13.93338^{* *}$ \\
2000 & 400 & 0.552 & $9.369940^{* *}$ \\
2001 & 411 & 0.669 & $12.90738^{* *}$ \\
Total & 6773 & 0.648 & $49.56342^{* *}$ \\
\hline
\end{tabular}

* Significant at $5 \%$ level.

** Significant at $1 \%$ level.

\section{Conclusions}

The empirical results show that firms will adjust their capital structure toward the industry mean when it is above the mean. But the probability that firms adjust the capital structure toward the industry mean is very low when it is below the mean, indicating that firms are indifferent to the debt level as long as it is below the industry mean. To explain this phenomenon, we developed the concept of optimal capital structure range within which a typical U.S. firm will be indifferent to its debt level. The empirical results strongly suggest that the likelihood a firm will use the internal financing as opposed to the external financing is very high. Furthermore, when a firm needs external financing, it generally prefers debt to equity. Our study thus shows that both the optimal capital structure hypothesis and the pecking order hypothesis coexist and that they are not mutually exclusive, as Claggett, Jr. had found. But the pecking order hypothesis is more pronounced than the optimal capital structure hypothesis as the former was significant for all the industries and for all the years, while the latter was significant for the majority of industries and for the majority of the years covered by our study.

Why does a firm adjust the capital structure toward the industry mean when it is above the mean, while it is indifferent when the capital structure is below the mean? The possible explanation for this is as follows: when a firm's debt level reaches a significantly high level, the high cost of the debt associated with the high leverage makes the reduction of the debt a meaningful task. That is why we observe more firms adjusting their debt level downward. But the firms which have below average debt level do not put the consideration of debt level as their first priority. Some other factors, such as the availability of the funds and market conditions may also play an important role in the consideration of the firm's capital structure.

\section{References}

1. Bowen, R.M., L.A. Daley, and C.C. Huber, Jr., 1982, "Evidence on the Existence and Determinants of Inter-industry Differences in Leverage," Financial Management, winter, 10-20.

2. Claggett, Jr., E.T., 1992, "Capital Structure: Convergent and Pecking Order Evidence," Review of Financial Economics, March, 35-48. 
3. Donaldson, G, 1961, "Corporate Debt Capacity: A study of Corporate Debt Policy and the Determination of Corporate Debt Capacity (Boston: Division of Research, Harvard Graduate School of Business Administration").

4. Ghosh, Arvin and Francis Cai, 1999, "Capital structure: new evidence of optimality and Pecking Order theory," American Business Review, 28, 32-38.

5. Goodman, L.A. and W.H. Kruskal, 1972, "Measures of Association for Cross-Classification, Part IV," Journal of American Statistical Association, 415-421; Part III, Ibid, 1963, 310-364; Part II, Ibid, 1959, 123 163; Part I, Ibid, 1954, 732-764.

6. Jalilvand, A., and R.S. Harris, 1984, "Corporate Behavior in Adjusting to Capital Structure and Dividend Targets: An Econometric Study," Journal of Finance, March, 127-145.

7. Lev, B., 1969, "Industry Averages as Targets for Financial Ratios," Journal of Accounting Research, autumn, 290-299.

8. Marsh, P., 1982, "The Choice between Equity and Debt: An Empirical Study," The Journal of Finance, March, 121-144

9. Modigliani, F., M. Miller, 1963, "Corporate Income Taxes and the Cost of Capital: A Correction," American Economic Review, 53, June, 433-443

10. ----, 1958, "The Cost of Capital, Corporation Finance, and the Theory of Investments," American Economic Review, 48, 261-297.

11. $\quad$ Myers, S.C., 1984, "The Capital Structure Puzzle," The Journal of Finance, July, 575-592.

12. Schwartz, E., J.R. Aronson, 1967, "Some surrogate Evidence in support of the concept of Optimal Financial Structure," Journal of Finance, March, 10-18.

13. Taggart, Jr., R.A., 1986, "Corporate Financing: Too Much Debt?" Financial Analysts Journal, May-June, $35-42$. 